\title{
TROPHY HUNTING: TO BAN OR NOT TO BAN? LEGAL PATHWAYS FOR ZIMBABWE IN THE AFTERMATH OF CECIL THE LION
}

\author{
Precious G. Makuyana*
}

\begin{abstract}
This article examines the legal framework and tools for achieving sustainable trophy hunting in Zimbabwe. Trophy hunting is part of wildlife tourism, in which wealthy tourists visit Zimbabwe to hunt for a unique, iconic wildlife with desirable phenotypic characteristics at a very high cost. The trophy hunting system was developed to achieve the tripartite objectives of conserving wildlife; providing local communities with economic opportunities and income; and incentivizing local communities to support environmental conservation initiatives. This article, however, highlights the blurred lines between the purported sustainable trophy hunting and its unsustainable implementation which now resembles "legal poaching." This dichotomy was heightened by the killing of Cecil the Lion, a tourism icon in Zimbabwe when it was not listed under the quota system for trophy hunting. The wellintentioned legal frameworks on sustainable trophy hunting in Zimbabwe are weakened by broad exceptions that render them toothless to achieve the intended tripartite sustainability objectives. As demonstrated in this article, these tripartite objectives can be fulfilled by effective enforcement mechanisms that do not currently exist. Proposals are recommended to promote these objectives through reformation of the existing legal frameworks. The option to ban trophy hunting is examined through a socioeconomic analysis in Zimbabwe to determine whether it would be possible to support a complete ban. Zimbabwe's current socioeconomic realities confirm that banning trophy hunting would be unlikely as doing so would devastate the tripartite objectives. Undertaking effective and sustainable policies is the more effective path for Zimbabwe at this time.
\end{abstract}

Keywords: Sustainability, Trophy Hunting, CITES; CAMPFIRE, Zimbabwe

DOI: https://dx.doi.org/10.4314/jsdlp.v9i1.7

* JD Candidate, College of Law, Florida A\&M University, United States. Email: precious1.ndebele@famu.edu 
A righteous man regards the life of his animal, But the tender mercies of the wicked are cruel.

- Proverbs 12:10 (NKJV) ${ }^{1}$

\section{INTRODUCTION}

Killing Cecil the Lion revealed the several regulatory challenges associated with trophy hunting in Zimbabwe. ${ }^{2}$ The key issue is whether Zimbabwe should completely ban trophy hunting and save the wildlife from torture and premature death? Or would such an outright ban inure to the detriment of vulnerable wildlife by enabling unregulated hunting that could lead to the extinction of the species? ${ }^{3}$

Furthermore, if sustainable trophy hunting is what is needed to achieve the tripartite objectives of sustainability, ${ }^{4}$ how can strong and effective policies, that protect wildlife, the local community, and the ecosystem, be established and enforced? When Cecil the Lion roared his last, was he the subject of legal sport-hunting that ended his life or was he unlawfully lured into a field that snuffed his revered presence from the Hwange National Park, after he had become the icon of Zimbabwe's wildlife tourism? The International Union for Conservation of Nature's (IUCN) briefing paper states, "while Cecil the Lion is perhaps the most highly publicized controversial case, there are examples of

1 The New King James Version of the Holy Bible.

2 Cecil was a Southern African lion that lived in Zimbabwe's National Park for many years. The lion became a subject of international media attention when it was wounded and killed on 1 July 2015 by the arrows of an American recreational trophy hunter, Walter Palmer. This event provoked widespread global condemnation from animal rights activists, environmental organizations and scholars on the need for global reform and rethink of trophy hunting practices. See BBC News, “Zimbabwe's 'Iconic' Lion Cecil Killed by Hunter” (27 July 2015) < https://www.bbc.com/news/world-africa-33674087> accessed 28 April 2018.

3 Annecoos Wiersema, "Incomplete Bans and Uncertain Markets in Wildlife Trade" [2016] 12 UPA Asian L Rev 65, 68 ("Yet for many of those most endangered species, CITES creates a type of dual system referred to as an incomplete ban.").

4 Karen Higginbottom, Wildlife Tourism: Impacts, Management and Planning (Common Ground Publishing Pty Ltd 2004) 5 ("the concept of Triple Bottom Line sustainability focusing on economic prosperity, environmental quality and social justice, has become widely adopted by major business players in the private sector and government," hence the tripartite objectives in this article mirrors sustainability's triple bottom line.). 
weak governance, corruption, lack of transparency, excessive quotas, illegal hunting, poor monitoring and other problems in a number of countries. ${ }^{5}$ As reinforced in the IUCN briefing paper, the lack of effective enforcements and accountability makes reform imperative. ${ }^{6}$

Trophy hunting is the hunting of animals with particular coveted uniqueness and overlaps with the widely practised hunting for meat. ${ }^{7}$ Trophy hunting refers to hunting by tourists, who select specific individual members of a species with extraordinary phenotypic traits (e.g., large horns, tusks, or black mane) and they are accompanied by a local professional hunter. ${ }^{8}$ Trophy hunting is part of wildlife tourism, where the tourist-hunter kills a specific animal selected through a quota system that chooses individual members of species to be legally allocated for harvest during a year and in a particular area. ${ }^{9}$ There are varied habitat areas for the wildlife to live in, which consists of a national park, a safari, sanctuaries, botanical reserves, or gardens and recreational parks. ${ }^{10}$

The challenge of managing trophy hunting is compounded by community-based conservation programmes such as the Communal Area Management Programme for Indigenous Resources (CAMPFIRE). ${ }^{11}$ CAMPFIRE was pioneered in Zimbabwe in the late 1980s and

5 International Union for Conservation of Nature, "Briefing Paper 2016: Informing Decisions on Trophy Hunting" (2016) 1 <https://www.iucn.org/ sites/dev/files/iucn_sept_briefing_paper_-_informingdecisionstrophy hunting.pdf $>$ accessed 28 April 2018.

6 Ibid.

7 Ibid.

8 Victor K Muposhi, Edson Gandiwa, Paul Bartels, and Stanley M Makuza, “Trophy Hunting, Conservation, and Rural Development in Zimbabwe: Issues, Options, and Implications" (2016) International Journal of Biodiversity 1 .

9 Ibid ("The quota system used is based on ecological theory, i.e., maximum sustainable yield (MSY), set in such a way that offtake levels are always below the growth rate of the target species at any given time.").

10 Zimbabwe Title XX Parks and Wildlife Act of 1975, Chapter 20:14 (Amended 1991) < https://www.unodc.org/res/cld/document/parks-and-wild-lifeact_html/Parks_And_Wild_Life_Act.pdf $>$ accessed 29 April 2018 (noting in the preamble that one of the purposes of the Act is " $[\mathrm{t}] \mathrm{o}$ provide for the establishment of national parks, botanical reserves, botanical gardens, sanctuaries, safari areas and recreational parks ...").

11 Johannes Bauer and Alexander Herr, "Hunting and Fishing Tourism" in Karen Higginbottom (ed), Wildlife Tourism: Impacts, Management \& Planning, Corporative Research Center for Sustainable Tourism (Common Ground Publishing Pty Ltd 2004) 72. 
implemented by the Department of National Parks, which gave the rural districts authority over their wildlife. ${ }^{12}$

Trophy hunting, which was originally meant to promote a set of tripartite objectives, threatens to undermine all three goals. ${ }^{13}$ The tripartite objectives, which include conserving wildlife, serving the local community, and preserving the environment, are analogous to the conventional triple bottom line ${ }^{14}$ in sustainable development. ${ }^{15}$

The counterintuitive effect of trophy hunting is apparent in that wildlife is now endangered ${ }^{16}$ through questionable killings as in Cecil the lion's hunt; the communities where these species reside are impoverished, and the ecosystems where these species reside have been neglected. ${ }^{17}$ A study by the U.S. Fish and Wildlife Service (USFWS) Law Enforcement Management Information System (LEMIS) that was conducted to ascertain the impact of American trophy hunters in other host countries between 2005 and 2014; revealed that more than 1,200 different kinds of animals were imported as trophies, ${ }^{18}$ and 32,500 of those trophies were from the Africa's Big Five Species. ${ }^{19}$

12 bid

13 Ibid 59. ("By using a Triple Bottom Line concept i.e. being socially, economically and environmentally accountable hunting/fishing can contribute to a holistic and sustainable conservation approach, as recent examples such as CAMPFIRE demonstrates.").

14 Josephine M Balzac, "Corporate Responsibility: Promoting Climate Justice Through the Divestment of Fossil Fuels and Socially Responsible Investment" in Randall S. Abate (ed), Climate Justice: Case Studies in Global And Regional Governance Challenges (Environmental Law Institute, 2016) 126 ("Sustainable development incorporates three elements: environmental protection, social development, and economic development," this triple bottom line concept of maintaining the wildlife, the local community, and the environment parallels with the sustainable development that informs the interdependency of each element in order to be preserved for future generations.).

15 Brundtland Report 1987, Our Common Future: Report of the World Comm'n on Env't \& Dev (1987), <http://www.un-documents.net/our-common-future.pdf> accessed 29 April 2018 ("Sustainable development is development that meets the needs of the present without compromising the ability of future generations to meet their own needs.").

16 International Fund for Animal Welfare, Exec Summary 2016: Killing for Trophies: An Analysis of Global Trophy Hunting Trade 4.

17 Bauer and Herr (n 10) 59.

18 The Humane Society International; The Humane Society of the US, Exec Summary 2016: Trophy Hunting by the Numbers: The US Role in Global Trophy Hunting 1 (2016).

19 Ibid (The study indicated that "approximately 5,600 African lions, 4,600 African elephants, 4,500 African leopards, 330 southern white rhinos and 17,200 African buffalo," were imported into the United States.). 
Trophy hunting was meant to be a resolution to the crisis of poaching, which was mainly a result of the poverty in the communal areas. It was meant to break the cycle of poverty sometimes that emanated from droughts or wildlife destroying the fields' crops, the main source of food for the family. Its purpose was to enhance the resources to keep the land productive for both human beings and wildlife. ${ }^{20}$ The solution provided an innovative stream of income for local communities and an incentive for them to protect wildlife.$^{21}$ Money from trophy hunting that infiltrates into the community provided relief against poverty and created an incentive for the conservation of wild life and other natural resources. ${ }^{22}$ Over the years, therefore, indigenous and local communities worldwide have supported trophy hunting as a strategy to leverage income generation, wildlife conservation and sustainable livelihoods. ${ }^{23}$ This tripartite solution was enforced through the grassroots initiative, CAMPFIRE. ${ }^{24}$

The United States Agency for International Development (USAID) was responsible for funding this community-based natural resource programme, which ensured community engagement in the protection of its indigenous resources. ${ }^{25}$ The political climate transformed the land ownership laws. The land grab from the commercial white farmers changed the once-blossoming and champion of tourism and wildlife management in Southern Africa to ruins. ${ }^{26}$ A country that once had an admired comprehensive health system boasted a coveted 98.9 per cent

20 Georgette Leah Burns, "The Host Community \& Wildlife Tourism" in Karen Higginbottom (ed), Wildlife Tourism: Impacts, Management and Planning (Common Ground Publishing Pty Ltd, 2004) 126 ("CAMPFIRE aims for people to continue farming whilst collecting profit from wildlife management.").

21 Ibid.

22 Ibid.

23 IUCN (n 4) 2.

24 Peter G.H. Frost and Ivan Bond, "The CAMPFIRE program in Zimbabwe: Payments for wildlife services” (2008) 65 Ecological Economics 776, 777 ("CAMPFIRE was developed around the concept of managing wildlife..."). ("By 2002, the CAMPFIRE Association represented 37 Rural District Councils, covering over $244,000 \mathrm{~km}^{2}$ and supporting some 777,000 households, though just 23 of these really functioned as intended.")

25 Ibid.

26 Roxanne Julianne Kovacs, "What Makes a Failed State? Examining the case of Zimbabwe" (E-International Relations, 31 May 2012) < http://www.e-ir.info/ 2012/05/31/what-makes-a-failed-state-examining-the-case-of-zimbabwe/> accessed 28 April 2018. 
literacy rate and was a leading exporter of agricultural products today lies on the brink of poverty. ${ }^{27}$ The lack of governance has thrown the once-strong economy into a tailspin, which may be the reason why Zimbabwe may not be able to sustain a complete ban of trophy hunting as is the case in Botswana. ${ }^{28}$

Given the continued relevance of trophy hunting to economic development in Zimbabwe, this article examines the legal framework and tools for achieving sustainable trophy hunting in Zimbabwe. Section 2 provides a background on wildlife tourism's sport - trophy hunting and how it was established to alleviate poaching and to benefit and sustain the wildlife, the local community, and the ecosystem. Section 3 examines the governing international and domestic legal frameworks on trophy hunting in Zimbabwe. These laws include the Convention on International Trade in Endangered Species of Wild Fauna and Flora (CITES) and the local initiative CAMPFIRE. ${ }^{29}$ It considers CAMPFIRE's current dissonance, the neglect of the local community, and the departure from its original vision to suppress poaching in order to give back to the community, and enhance the value of the wildlife in the community. ${ }^{30}$

Section 4 proposes solutions that are feasible for Zimbabwe, such as amendments to CITES and CAMPFIRE's legal frameworks to enhance their effectiveness. It discusses how CITES can be amended to eliminate exceptions in Appendix I listings, and to reduce allowances for the remaining appendices, in order to effectively address trade in endangered species. Moreover, it discusses an amendment to CAMPFIRE to create a Finance Task Force that will include a strong representation from the local community to foster transparency and accountability. Furthermore, the community shall be able to exercise their right to sue for compensation. The article concludes in section 5.

27 Samantha Power, "How to kill a country: Turning a breadbasket into a basket case in 10 easy steps - the Robert Mugabe Way" The Atlantic (December 2003) $<$ https://www.theatlantic.com/magazine/archive/2003/12/how-to-kill-acountry/302845/ $>$ accessed 28 April 2018.

28 Kovacs (n 26).

29 Frost and Bond (n 23) 776. (CAMPFIRE was pioneered in Zimbabwe and has been emulated in Africa.).

30 Ibid 776-77. (This was originally viewed as a menace destroying the livelihoods of the community when wildlife went into the field and destroyed their crops and sometimes killing their livestock.) 


\section{SUSTAINABLE TROPHY HUNTING OR SUSTAINABILITY}

On 5 September 2017, the United Nations General Assembly adopted a resolution, "Tackling Illicit Trafficking in Wildlife, reinforcing the great need for heightened sustainable wildlife management." ${ }^{31}$ It reaffirmed that "the intrinsic value of biological diversity and its various contributions to sustainable development and human well-being ... are an irreplaceable part of the natural systems of the earth which must be protected for this generation and the generations to come."32 Sustainable trophy hunting should be good for conservation that is a proponent's banner; however, this has been undermined by the current practices that mirror poaching. ${ }^{33}$ A reduction in trophy size of particular and popular species may decrease the competitive advantage of the destination. Thus the sustainability of trophy hunting as a conservation tool is weakened. ${ }^{34}$ However, with effective policies and administration, trophy hunting can have positive impacts. ${ }^{35}$

\subsection{Harm to Wildlife}

The contemplation of harm to wildlife in Zimbabwe focuses attention on the threat to some of "the Big Five". The Big Five ${ }^{36}$ consists of lion, elephant, rhino, leopard, and the African buffalo, animals that are often targeted for capture as trophies. ${ }^{37}$ Elephants $^{38}$ and rhinos ${ }^{39}$ are killed

31 GA Res 71/88, UN Doc A/RES/71/L88, UN Resolutions, Tackling illicit trafficking in wildlife (Sept 5, 2017).

32 Ibid A/71/L 88 (The concept of protecting beyond the present but for the future generation has been a recurring theme of sustainable development.).

33 IUCN (n 4) 5.

34 Victor K. Muposhi, Edson Gandiwa, Paul Bartels, Stanley M. Makuza \& Tinaapi H. Madiri, "Trophy Hunting and Sustainability: Temporal Dynamics in Trophy Quality and Harvesting Patterns of Wild Herbivores in a Tropical Semi-Arid Savanna Ecosystem" (2016) PLOS ONE 1.

35 IUCN (n 4) 5.

36 The Humane Society International (n 17) 1.

37 International Fund for Animal Welfare (n 15) 10. (SCI's has a reward program “. . . for example a hunter must kill an elephant, rhino, lion, leopard, and African buffalo to get on the African Big Five Grand Slam list.").

38 The Humane Society International, (n 17) 14. ("Just between 2010 and 2012, 100,000 African elephants were poached....").

39 Ibid (The southern white rhino is listed as Near Threatened on the IUCN Red List and Threatened under the ESA. Southern white rhino hunts can cost USD $\$ 55,000-150,000$. 
mainly for their precious ivory tusks. In an article that calls Cecil the Lion's death "murder," 40 the author laments that legal trophy hunting is no longer different from poaching and states that "well over 100,000 elephants were killed in Africa since 2011; and as to Cecil's brethren, their numbers and their land are dwindling daily...". The article concludes that "whatever 'conservation' effort trophy hunters think they are contributing to, it's not working." 41

The black rhino is listed as critically endangered; its population "has declined by an estimated 97.6 per cent since 1960 with numbers bottoming out at 2,410 in 1995 , mainly as a result of poaching." 42 Nonetheless, the black rhino population has been steadily increasing at a continental level with numbers doubling to 4,880 by the end of 2010, yet the current numbers are still 90 per cent lower than they were three generations ago. ${ }^{43}$ The black rhino has been listed on CITES Appendix I since 1977, and international commercial trade in black rhinos and their products has been prohibited. ${ }^{44}$ Trophy hunting critics argue that "poaching has not been curtailed but bolstered," and emphasize that a trophy hunting operation may be a channel for poaching. ${ }^{45}$ Additionally, as indicated by an indigenous spokesman, "[t]rophy hunting in Zimbabwe's Matetsi Safari Area is not sustainable at current levels as trophy sizes are declining, there is little scientific data supporting quota sizes, and hunting management is seriously incapacitated." 46 Moreover, the trophy size and harvesting patterns in these species pose a conservation and management dilemma on the sustainability of trophy hunting in this area. ${ }^{47}$ The cruel irony is that the principles of economics are at play. As a species becomes rarer, its

40 Jena Hunt, "The Other Cecils: The Unnamed Victims of Poaching and Trophy Hunting" (One Green Planet, 18 November 2015) < http://www.onegreen planet.org/animalsandnature/unnamed-victims-of-poaching-and-trophyhunting/> accessed 28 April 2018.

41 Ibid.

42 IUCN Redlist, "Diceros bicornis" < http://www.iucnredlist.org/details/6557/ 0> accessed 28 April 2018.

43 Ibid.

44 Ibid.

45 Hunt (n 40).

46 Andreas Wilson-Spath, "Problems with trophy hunting in Zimbabwe exposed", Conservation Action Trust, 22 November $2016<$ https://conservationaction. co.za/media-articles/problems-trophy-hunting-zimbabwe-exposed/> accessed April 282018.

47 Muposhi and others, Trophy Hunting and Sustainability (n 34). 
value increases, thereby increasing the incentive for further poaching. ${ }^{48}$ Furthermore, between 1981 and 1989, "elephant population was reduced by half mainly due to trade in ivory." 49

In response to the dramatic decline of lion populations in the wild, the USFWS announced in December 2015, five months after the renowned death of Cecil the Lion, that it would list two lion subspecies under the ESA. ${ }^{50}$ Fewer than 21,000 lions remain in Africa today. ${ }^{51}$ The potential for loss of a top predator in its ecosystem, the king of the jungle, hints at the potential ruinous outcome this extinction could produce on the world. ${ }^{52}$

On the other hand, IUCN has reported that "while there is evidence for a small number of populations that unsustainable trophy hunting has contributed to local declines; it is not a significant threat to any of these species and is typically a negligible or minor threat to African wildlife populations. ${ }^{53}$ The report indicates that the principal causes of the decline of wildlife such as the elephant, buffalo, white and black rhino are habitat loss, competition with livestock, uncontrolled poaching for meat and ivory, and retribution killing for human-wildlife conflict instead of trophy hunting. ${ }^{54}$ Furthermore, the lion's decline in number is attributed to defence killing by humans to protect human life and livestock; habitat loss; and the depletion of its prey base caused by poaching. ${ }^{55}$ Conversely, critics attest that instead of trophy hunting

48 David Hunter, James Salzman and Darwood Zaelke, International Environment Law and Policy (3rd edn, New York : Foundation Press: Thomson/West, University casebook series 2007) 1095 ("The demand for scarce wildlife products such as elephant ivory, black rhinoceros horns, and tiger bones ...have driven many species to the brink of extinction.").

49 Ibid.

50 USFWS, "Endangered Species Act Listing Protects Lions in Africa and India, Director's Order Strengthens Wildlife Import Restrictions for Violators of Wildlife Laws" (Press Release, 21 December 2015) < https://www.fws.gov/news/ ShowNews.cfm?ref=endangered-species-act-listing-protects-lions-in-africaand-india-\&_ID=35403> accessed 29 April 2018 ("In the wake of Cecil the Lion's death, "[a]s of January 22, 2016, the United States (U.S.) Federal Register reflects a significant addition to the Endangered Species Act.") (USFWS Press Release).

51 Madison Clemens, "Cecil the Lion: The Everlasting Impact on the Conservation \& Protection of the King of the Jungle" (2017) 28 Vill Envtl LJ 51, 51-2, 70 (noting that twice the amount of lions existed in Africa until the 1950s.).

52 Ibid 55.

53 IUCN (n 4) 7.

54 Ibid.

55 Ibid. 
conserving the wildlife and implementing a sustainable approach to natural resources management, it has played a role in the decline of wildlife. ${ }^{56}$

The USFWS states that, "[i]n the last 20 years, lion populations have declined by 43 per cent due to habitat loss, loss of prey base, and retaliatory killing of lions by a growing human population. ${ }^{57}$ This decline is exacerbated by inadequate financial and other resources for countries to effectively manage protected areas as the impact on lions in the wild has been substantial. ${ }^{58}$

The IUCN's 2015 Red List assessment of Panthera leo details serious declines in lion populations across much of its African range. ${ }^{59}$ Lion populations in West, Central, and East Africa are predicted to suffer a further projected 50 per cent decline over the next two decades. ${ }^{60}$ Although the IUCN has maintained the lion's "vulnerable" Red List status, sample lion populations outside of Botswana, Namibia, South Africa, Zimbabwe, and India have been observed to have declined by more than 60 per cent from 1993-2014 and the lion, therefore, meets the criteria for an endangered listing in the majority of its range. ${ }^{61}$ The West African sub-population, which is perceived to just have over 400 individuals, is distinctly classified by the IUCN as "critically endangered." 62

This widespread disregard for wildlife has created substantial injustice for present and future generations through ecosystem disruption. Indeed, there are genuine and controlled demands, where wild plants and animals may be exchanged across borders to meet demands for food, pets, medicines, where these goods are not native. ${ }^{63}$

56 Nels Paulson, "The Place of Hunters in Global Conservation Advocacy" (2012) Conservation and Society 53, 61 (discussing the hunting-conservation paradox).

57 USWFS Press Release (n 50).

58 Ibid.

59 IUCN Redlist (n 42).

60 Ibid.

61 Convention on International Trade in Endangered Species of Wild Fauna and Flora [CITES] E CoP17 Prop4 (2016), Seventeenth meeting of the Conference of the Parties (CoP) Johannesburg (South Africa), Sep 24 - Oct 05, 2016, <https://cites.org/sites/default/files/eng/cop/17/prop/060216/E-CoP17Prop-04.pdf $>$ accessed 28 April 2018 (CITES E CoP17).

62 Ibid.

63 Leslie Couvillion, "Habitat Loss, Agrobiodiversity, and Incidental Wildlife Loss" in Gabriela Steier and Kiran K Patel (eds), International Farm Animal, Wildlife and Food Safety Law (Springer 2017) 764. 
The ultimate lust has engulfed the African wildlife, and a black market is the order of the day, which results in a black day for that elephant, rhino, or lion. The widespread decline of these species has been enabled by the loopholes in the current governing laws.

\subsection{The Demand for Ivory}

The insatiable demand of Southeast Asian ivory market, particularly China and Vietnam, represents 40-70 per cent of the global ivory black market. ${ }^{64}$ The elephant and the rhino are at the mercy of the ruthless killers. Hence their population continues to decline, with only an estimated 400,000 elephants remaining in Africa. ${ }^{65}$ Studies have shown that between 2011 and 2014, poachers have killed 100,000 elephants for their tusks, and it is estimated that an elephant is killed every fifteen minutes for its tusks. ${ }^{66}$

Poachers are considered to be the greatest threat to the survival of elephants. Consequently, rhinoceroses are at a point of extinction. ${ }^{67}$ Rhino horns are valued by Asian traditional medicine buyers and are a key target of traffickers. ${ }^{68}$ Western black rhinoceroses are already considered to have become extinct in $2011 .{ }^{69}$ The killing of Zimbabwe's elephants for their ivory tusks has also drawn global attention, as has a spate of poaching-related, cyanide-based poisonings that reportedly primarily targeted elephants and rhinos and affected multiple species. ${ }^{70}$ An estimated 400 or more elephants have reportedly been killed in this manner since 2008, including about 70 in 2015 in Hwange and other parks in Zimbabwe, along with several hundred rhinos in recent years. ${ }^{71}$

The drastic disturbance of the wildlife and its ecosystem is unprecedented, where smugglers have disguised poaching as legal

64 Sabrina Persaud, "Losing Our "CITES" on the "Traffic": How Taxing Ivory Trafficking Can Save the African Elephant from its Bloody Extinction" (2017) 20, Journal of International Wildlife Law and Policy, 295.

65 Ibid.

66 Ibid.

67 Ibid.

68 CRS Report, Congressional Research Services, CRS Report, Zimbabwe: Current Issues and US Policy, 23 (Sept 15 2016)

69 Dellinger (n 67) 407.

70 CRS Report Zimbabwe (n 69) 23.

71 CRS Report Zimbabwe (n 69) 23. 
trophy hunting and to the extent of using bribes. ${ }^{72}$ In 2015, the Minister of Environment, Water and Climate, deployed the national army to supplement game warden and police poaching patrol of activities in several large game parks using helicopters, drones, and other methods. ${ }^{73}$ This became imperative after authorities arrested a group of game wardens and some villagers near Hwange in connection to cyanide poisoning where a poacher was killed and his accomplices arrested. ${ }^{74}$ Nevertheless, programmes, such as drone surveillance, DNA database recordings, and even poisoning the horns to deter poaching have achieved little success due to the high value placed by some on rhinoceros horn, which is currently selling for a higher price per pound than gold, diamonds, or cocaine. ${ }^{75}$

\subsection{Socioeconomic Factors Are the Drivers of the Harm}

Political, social, cultural, and economic factors play an inextricable role in determining the rate of success of any governing laws. ${ }^{76}$ Political instability causes a domino effect that drives cultural tensions, social disorder, and the collapse of an economy. ${ }^{77}$ The role of economic instability ${ }^{78}$ in Zimbabwe has caused adverse consequences on a oncecelebrated and sustainable wildlife tourism and conservation management system. While hunting is a significant source of conservation income nationally, generating US\$45 million in 2014 according to the Zimbabwe Parks and Wildlife Management Authority, it is controversial. ${ }^{79}$ The social and economic disorder inspires desperation that prompts reliance on poaching, which adversely affects

72 Persaud (n 64). ("Tons of ivory have gone unnoticed at the ports because of bribery.").

73 CRS Report Zimbabwe (n 69) 23.

74 Ibid.

75 Dellinger (n 67) 407. ("Rhino horn was reported to be selling at higher value, making it more expensive by weight than gold, diamonds or cocaine.").

76 CRS Report Zimbabwe (n 69) 27.

77 Ibid ("Land seizures, state-centric economic policies, and persistent political turmoil under Mugabe led to a severe economic contraction between 2000 and $2009 \ldots . .$.$) .$

78 ibid 14. ("Zimbabwe's Central Bank has identified illicit financial flows worth hundreds of millions of dollars annually-in the form of illicit cross-border bank transfers, trade mispricing..., as a key economic challenge.”).

79 CRS Report Zimbabwe (n 69) 23. 
wildlife's conservation and preservation of the environment. Management of wildlife and enforcement of protection mandates are critical to conservation efforts, as poverty, civil unrest, and other factors can lead to illegal use and over-exploitation of these vulnerable resources. ${ }^{80}$

Social status and cultural dimensions also shape the debate on trophy hunting. ${ }^{81}$ The use of hunting opportunities as a conservation tool, however, has led to differences of opinion over whether wildlife should or should not be killed to promote conservation objectives. ${ }^{82}$ On the other hand, an indigenous observer in the developing world, one with the first-hand experience of sharing the habitat space with the wildlife, perceives trophy hunting as an amicable compromise. ${ }^{83}$

The local community may live in such proximity to the wildlife that at times it may cause death to humans and destroy crops; this is prevalent when the wildlife number increases to the extent that it is competing for living space with the humans. ${ }^{84}$ In order to create harmony and reduce the wildlife and human conflict, ${ }^{85}$ trophy hunting has been the solution that not only brings resources to maintain the natural resources and enhance conservation efforts but also enhances the livelihood of the community. ${ }^{86}$

80 Southern African Development Community (SADC), Food, Agriculture and Natural Resources (FANR) Directorate, "Natural Resources" < http:// www.sadc.int/themes/natural-resources/> accessed 28 April 2018.

81 Dellinger (n 67) 402.

82 Leader-Williams and others, "Trophy Hunting of Black Rhino Diceros Bicornis: Proposals to Ensure Its Future Sustainability" (2005) 8 Journal of International Wildlife Law and Policy 1, 3 (discussing the controversy behind trophy hunting as a conservation tool).

83 Glen Martin, "Lionizing Cecil Makes Us Feel Good, But A Trophy Hunting Ban Will Accelerate Slaughter" California Magazine (3 August 2015) <https:// alumni.berkeley.edu/california-magazine/just-in/2015-10-08/lionizing-cecilmakes-us-feel-good-trophy-hunting-ban-will> accessed 16 November 2017.

84 The Humane Society International (n 17) 7.

85 Lindah Mhlanga, "Conflict between Wildlife and People in Kariba Town Zimbabwe" (2001) 27 Michigan State University Africa-ejournals 39 ("Elephants and buffaloes damage and destroy property and frighten or kill people ... but there is no compensation for death, injury or property damaged by animals.").

86 CRS Report Zimbabwe (n 69) 25. ("Under the CBNRM model, community groups often manage natural resource zones, and communities benefit from resulting jobs, tourism proceeds, and limited, regulated hunting."). 
IUCN highlights that the local community benefit from trophy hunting, which support infrastructure, schools and health clinics, and promote an increase in employment. ${ }^{87}$ Conversely, a closer look at trophy hunting indicates that the industry employs only a few people ${ }^{88}$ and that the money from hunting fees that trickles down to needy villagers is minimal. ${ }^{89}$ The critics of trophy hunting suggests that corruption could be a factor that is comingled with governmental operations such as allocating lucrative hunting areas to a specific class of people outside the impoverished local community. ${ }^{90}$ Moreover, they argue trophy hunting has not stopped poaching, ${ }^{91}$ particularly in countries that have a poor record of wildlife conservation. ${ }^{92}$

\section{CURRENT LEGAL FRAMEWORK ON TROPHY HUNTING}

The governing framework on trophy hunting consists mainly of international instruments, and their local implementation in Zimbabwe, that aim to protect wildlife, safeguard the local community and the preservation of the ecosystem.

\subsection{The Convention on International Trade in Endangered Species (CITES)}

The Convention on International Trade in Endangered Species of Wild Fauna and Flora (CITES) Conference of the Parties (CoP) has expressly acknowledged that commercial trade in wildlife may be beneficial to

87 IUCN (n 4) 7.

88 International Fund for Animal Welfare (n 15) 11. ("The photographic sector operates year-round versus predominantly during the hunting season, therefore it can host a larger number of guests, employs more people....").

89 Adam Cruise, "Is Trophy Hunting Helping Saving Elephants? Fees from trophy hunting of elephants that are supposed to help local communities and elephants often do not", National Geographic, 17 November $2015<$ https://news.national geographic.com/2015/11/151715-conservation-trophy-hunting-elephantstusks-poaching-zimbabwe-namibia/> accessed 28 April 2018.

90 Ibid.

91 Dellinger (n 67) 407. (Nevertheless, "[t]o be sure, trophy hunting is not the same as poaching, although some question whether the former is, in fact, a disguise for the latter.").

92 Cruise (n 90). 
species conservation and to the host community. ${ }^{93}$ It has been shown that illegal wildlife trade is estimated to earn from US\$5 to US $\$ 40$ billion annually. ${ }^{94}$ Further studies highlight that illegal trade in wildlife is quite lucrative and ranks third in profitability after drugs and weapons smuggling and is responsible for an estimated 40 per cent of species facing extinction. ${ }^{95}$

CITES regulates the global trade in species that are threatened with extinction. ${ }^{96}$ It is a treaty that seeks to ensure that trade in species and specimens of wildlife and plants does not threaten their survival. ${ }^{97}$ CITES establishes a system of import and export regulations to prevent the overexploitation of plants and animals listed in three appendices to the Convention. ${ }^{98}$ It acts as a border security guard restricting the flow of rare species and parts of species across national borders. ${ }^{99}$ Different levels of trade regulations are imposed depending on the status of the listed species and the contribution trade makes to the decline of species. ${ }^{100}$ Procedures are provided for periodic amendments to the appendices. ${ }^{101}$

CITES was signed by 80 nations in Washington, D.C., on 3 March 1973 and it entered into force on 1 July $1975 .{ }^{102}$ CITES currently covers $183^{103}$ member states, including Zimbabwe, which joined by accession on 5 May 1981, and the convention entered into force in Zimbabwe on 17 August 1981. ${ }^{104}$ Zimbabwe's implementation of trophy hunting embraces CITES' "sustainable use" paradigm, which argues that there is a level of utilization of wildlife that is sustainable and results in

93 Thomas G Kelch, "CITES, Globalization, and the Future of Animal Law" in Randall S. Abate (ed), Climate Justice: Case Studies in Global And Regional Governance Challenges (Environmental Law Institute 2016) 269.

94 Ibid 279.

95 Hunter and others (n 48) 1095.

96 Ibid 1096.

97 CITES, "Checklist of CITES Species" (2017), < http://checklist.cites.org/\#/ en Index_of_CITES_Species_2017-10-01 20-51.pdf> accessed 28 April 2018 (Checklist of CITES).

98 US Fish and Wildlife Service, "Digest of Federall Laws" < https://www.fws.gov/ laws/lawsdigest/treaty.html\#CITES> accessed 28 April 2018.

99 Hunter and others (n 48) 1096.

100 Digest of Federal Laws (n 99).

101 Ibid.

102 Ibid.

103 Couvillion (n 63) 764.

104 CITES Zimbabwe, "National Contacts" < https://cites.org/eng/cms/index.php/ component/cp/country/ZW> accessed 28 April 2018. 
substantial economic and other benefits. ${ }^{105}$ CITES employs the "sustainable use"106 paradigm to regulate and control the effects of trophy hunting. The purpose of this approach is to "to conserve biodiversity and contribute to its sustainable use by ensuring that no species of wild fauna or flora becomes or remains subject to unsustainable exploitation through international trade, thereby contributing to the significant reduction of the rate of biodiversity loss." 107

CITES' regulatory scheme consists of a three-tiered appendix listing system that regulates trade in endangered species at different levels of stringency depending on the appendix in which a particular species is listed. ${ }^{108}$ These three appendices establish differing levels of permit requirements for the import and export of endangered and threatened species. ${ }^{109}$ There are over 35,000 plant and animal species that are listed across the three appendices. ${ }^{110}$ The species may either be (a) threatened, and protected under Appendix I; (b) at risk of becoming threatened, and protected under Appendix II; or (c) protected in at least one country, which has asked other Parties to control their trade, and protected under Appendix III. ${ }^{111}$

Appendix I lists species threatened with extinction that are or may be affected by trade. ${ }^{112}$ "Appendix I trade is limited to only scientific and educational purposes and to some hunting trophies." 113 Whereas Appendix I is viewed as the most restrictive of the three appendices, its regulatory weakness is its allowance of trade even for threatened species that are facing extinction. ${ }^{114}$ The "narrow exceptions" include conducting trade only if both the exporting and importing countries issue permits and consent to the international trade. ${ }^{115}$ This narrow

105 Kelch (n 94) 271.

106 Ibid.

107 CITES, "What is CITES?" (2018) < https://www.cites.org/eng/disc/ what.php $>$ accessed 28 April 2018.

108 Ibid.

109 Hunter and others (n 48) 1096.

110 Couvillion (n 63) 764.

111 Couvillion (n 63) 764.

112 Hunter and others (n 48) 1096.

113 Kelch (n 94) 276.

114 Lakshman D. Guruswamy, Kevin L. Duran, International Environmental Law in a Nutshell(4th edn, Thomson / West, 2012) 198.

115 Hunter and others (n 48) 1096-97. 
exception has broad parameters and implementation measures that may not be foreseeable dangers between developed countries. This CITES provision, which leaves it up to the importing country's discretion as to whether its Scientific Authority must confirm the export will not be detrimental to the species survival, and its Management Authority to confirm the specimen will not be used for "primarily commercial purposes," is a dangerous loophole. ${ }^{116}$

For instance, a developing country that needs foreign currency to sustain its economy may not consider the species' interest and may also enter into an agreement with a country that has a high demand for ivory and may act against its Scientific Authority's ruling to pursue this trade at the expense of the species' survival. The loophole does not consider that trade among countries may be motivated by different pressures and purposes; hence safeguarding the wildlife's interest may not be a priority.

Furthermore, permitting wealthy individuals to kill some of the very last few specimens of rare species has been indicated as repugnant to many members of the public that courts must consider these contracts unenforceable for reasons of public policy. ${ }^{117}$ Indeed, the issue becomes whether CITES, which is meant to safeguard the sustainability of endangered species, is effectively implementing protective measures through a ban that may be illusory. Yet, for many of those most endangered species, CITES creates a type of dual system called an incomplete ban. ${ }^{118}$ The increased decline in elephants, for instance, may reflect CITES' failure in its implementation, particularly in permitting a reservation for Zimbabwe, Namibia, and South Africa for an Appendix I species. ${ }^{119}$

Appendix II includes species not necessarily now threatened with extinction, but that may become so unless specimens of such species are subject to strict regulation such that trade in the specimens of other species is brought under effective control. ${ }^{120}$ Appendix II is by far the largest appendix with over 32,000 listed species, including the narwhal, American alligator, and polar bear. ${ }^{121}$ The African Elephant

116 ibid.

117 Dellinger (n 67) 397.

118 Wiersema (n 2) 67.

119 Guruswamy (n 115) 197.

120 Kelch (n 94) 277.

121 Hunter and others (n 48) 1097. 
found in the savannah region and in Southern Africa, known by its scientific name as Loxondota Africana, is currently listed in Appendix II as a threatened species, where trade in hunting trophies for noncommercial purpose is permitted. ${ }^{122}$ Trade in Appendix II species requires the issuance of an export permit but not an import permit. ${ }^{123}$

Zimbabwe seeks to amend the present Appendix II listing of its population of Loxodonta Africana by removing the annotation in order to achieve an unqualified Appendix II listing. ${ }^{124}$ An annotation is "used to qualify the permitted extent of trade in Appendix II species." 125 This annotation specifies that certain specimens can be traded and "[a]ll other specimens [which includes all raw elephant ivory] shall be deemed to be specimens of species included in Appendix I and the trade in them shall be regulated accordingly." ${ }^{126}$ The annotation includes a restriction in international trade of elephant parts (the ivory), as if it were listed in Appendix I. The annotation applies to the elephant population of Botswana, Namibia, South Africa, and Zimbabwe. ${ }^{127}$ In the case of the African elephant populations of Botswana, Namibia, South Africa, and Zimbabwe, a legally binding annotation to the Appendix II listing deems elephant ivory from these populations as being on Appendix I even though the populations are included in Appendix II. ${ }^{128}$ Therefore, all commercial international trade in the ivory of African elephants is currently prohibited under CITES. ${ }^{129}$

1221 Checklist of CITES (n 98) 1265.

123 Hunter and others (n 48) 1097.

124 CITES (n 61).

125 Convention on International Trade and Endangered Species of Wild Fauna \& Flora (CITES), "E-Cop17-Prop15 Consideration of Proposals for Amendment of Appendices I and II" (2016) < https://cites.org/sites/default/files/eng/ cop/17/prop/060216/E-CoP17-Prop-15.pdf > accessed 29 April 2018 (CITES Zimbabwe's Proposal).

126 Convention on International Trade and Endangered Species of Wild Fauna \& Flora (CITES), "Appendices" (2017) < https://cites.org/eng/app/ appendices.php $>$ accessed 29 April 2018.

127 CITES Zimbabwe's Proposal (n 126) Annex 1 Page 19 (Annotation on the CITES Appendices applying to the elephant populations of Botswana, Namibia, South Africa and Zimbabwe (listed in Appendix II)).

128 CITES, "Current rules on Commercial international trade in Elephant Ivory under CITES and Proposals to CITES CoP17" , (21 July, 2016) <https:// cites.org/eng/news/Current_rules_commercial_international_trade_e lephant_ivory_under_CITES_Proposals_CITES_CoP17_200716> accessed 19 June $20 \overline{18 .}$

129 Ibid. 
Appendix III species are listed when a party currently protects the species under its domestic laws and now seeks further cooperation of CITES parties to control its international trade. ${ }^{130}$ Since this listing includes species least threatened by trade, ${ }^{131}$ the party merely requires trade cooperation of other parties to protect the species. ${ }^{132}$ There is no need for the vote at the Conference of Parties, as is required for the first two appendices, ${ }^{133}$ to list or amend the listing. ${ }^{134}$ The Management Authority reviews that the exported specimen was not obtained in breach of the State's laws after an export license has been issued. ${ }^{135}$ CITES requires a Certificate of Origin for all trade in Appendix III species, even if the transaction involves parties that have not listed species in Appendix III. ${ }^{136}$

CITES' successes have been asserted as its strong track record to conserve wildlife. Its failures include its ineffective restrictions on threatened species listed in Appendix I. Furthermore, its successes are evident in Namibia and South Africa, where [s] ince the approval of limited rhino hunting quotas by CITES in late 2004, their numbers have increased by 67 per cent from 2,300 to 3,900. ${ }^{137}$

Like CITES, the Southern African Development Community (SADC) recognizes the importance of conservation and sustainable use of wildlife resources in Southern Africa. ${ }^{138}$ SADC expresses that "[w]ildlife tourism is an increasingly important and growing industry that brings benefits to private sector tourism businesses and local people alike."139 Through capacity building and regional integration, SADC addresses two key aspects of the United Nations Millennium Development

130 Hunter and others (n 48) 1098.

131 Ibid.

132 Kelch (n 94) 278.

133 Hunter and others (n 48) 1098.

134 Guruswamy (n 115) 196.

135 Hunter and others (n 48) 1098.

136 Guruswamy (n 115) 196.

137 IUCN (n 4) 11.

138 Maria Teresa Cirelli and Elisa Morgera, Wildlife Law in the Southern African Development Community (CIC and FAO 2010) 18 (Southern African Development Community, (SADC), it is an intergovernmental organization for 15 Southern African nations; its Regional Protocol on preserving natural resources requires that each party must ensure conservation and sustainable use of wildlife.).

139 SADC Natural Resources, "Wildlife" (2017) < http://www.sadc.int/themes/ natural-resources/wildlife/> accessed 29 April 2018. 
Goals, ${ }^{140}$ namely, sustainable use of natural resources; and eradicating poverty. ${ }^{141}$ Important natural resources include water, wildlife, and minerals. ${ }^{142}$ To help protect these resources and foster regional cooperation, protocols and initiatives such as the development of Trans-frontier Conservation Areas (TFCA) have been spearheaded by SADC. ${ }^{143}$ TFCAs are designed to collaboratively manage shared natural and cultural resources across international boundaries for improved biodiversity conservation and socioeconomic development, which enhances and complements CITES vision. ${ }^{144}$

Like most other African countries, Zimbabwe inherited from its colonial past a system of State ownership of wildlife that resulted in a decline of wildlife outside of protected areas. ${ }^{145}$ The Parks and Wildlife Act of 1975 (PAWA) provides private landholders in pre-independent Zimbabwe the right to manage wildlife for their own benefit, and this heralded an immediate reversal in wildlife declines on private land. ${ }^{146}$ The Act's provisions and functions embrace advocacy for sustainable wildlife management and reinforces the objectives set to be achieved through CITES as well as SADC. However, under the current and challenging Land Reform Programme, this number has changed and wildlife conservation efforts have declined.

In 1982, the legal provisions of PAWA were extended to Rural District Councils (RDCs) on behalf of rural communities in communal

140 UN Development Programme, "Sustainable Development Goals (SDGs)" (2017) <http://www.undp.org/content/undp/en/home/sustainable-developmentgoals.html> accessed 29 April 2018 ("These 17 Goals build on the successes of the Millennium Development Goals, while including new areas such as climate change, economic inequality, innovation, sustainable consumption, peace and justice, among other priorities.").

141 SADC Natural Resources (n 140).

142 Ibid.

143 Ibid SADC Transfrontier Conservation Areas. A TFCA is defined in the SADC Protocol on Wildlife Conservation and Law Enforcement (1999) as "a component of a large ecological region that straddles the boundaries of two or more countries encompassing one or more protected areas as well as multiple resource use areas."

144 Ibid.

145 Safari Club International, "Hunting is Conservation: The CAMPFIRE Program in Zimbabwe" (Safari Club International, 21 September 2015), <https:// huntforever.org/2015/09/21/hunting-is-conservation-the-campfireprogram-in-zimbabwe/> accessed 29 April 2018.

146 Ibid. 
lands in whose areas viable populations of wildlife are found. ${ }^{147}$ It enabled them to manage and benefit from wildlife resources through the programme called Community Areas Management Programme for Indigenous Resources, popularly known as CAMPFIRE. ${ }^{148}$

\subsection{Communal Areas Management Programme for Indigenous Resources (CAMPFIRE)}

CAMPFIRE, a 1989 initiative, is a Zimbabwean community-based natural resource management programme in which Rural District Councils, on behalf of communities on communal land, are granted the authority to market access to wildlife in their district to safari operators. ${ }^{149}$ The safari operators then sell the hunting and photographic safaris to international tourists, mostly sport hunters and ecotourists. ${ }^{150}$ This form of tourism has been instrumental in the development of highly successful community conservation models such as CAMPFIRE in Zimbabwe. ${ }^{151}$ In 1995, nearly half of Zimbabwe's fiftyfive districts (most of which still contained good numbers of wildlife) had signed on to the programme, twelve of which were earning US $\$ 1.5$ million in trophy fees, and an additional US\$97,732 from tourism, culling, and the removal of problem animals. ${ }^{152}$

From 1989-2001, CAMPFIRE generated over US\$20 million of revenue for the participating communities, 89 per cent of which came from game hunting. ${ }^{153}$ The then-novel and innovative approach was rooted in the "community conservation paradigm," 154 that today merely exists on paper. CAMPFIRE seeks to ensure that communities continue farming while collecting profit from wildlife management. ${ }^{155}$ Consumptive wildlife tourism in the form of hunting is encouraged in the programme. Local villagers receive 70 per cent of the license fees

147 Ibid.

148 Cirelli and Morgera, (n 139) 120. ("The Wildlife Based Land Reform Policy promotes secure and equitable tenure in the form of leasehold, freehold and communal tenure, and "indigenization" of the wildlife sector.).

149 Frost and Bond (n 29) 776. ("The District Councils pay the communities a dividend according to an agreed formula.").

150 Ibid 777.

151 Higginbottom (n 3) 60.

152 Ibid 72.

153 Frost and Bond (n 29) 777.

154 Ibid.

155 Higginbottom (n 3) 126. 
that contribute to individual household and shared community needs such as schools and health clinics. ${ }^{156}$

Species management projects, such as CAMPFIRE in Zimbabwe, have seen a degree of success in giving local people a real and tangible interest in local conservation activities. ${ }^{157}$ Examples of CAMPFIRE conservation activities include local game scout training and employment, local wildlife censuses, environmental education, poaching prevention activities, and species preservation, including through flora preservation and transfers of wildlife between speciesrich and species-poor areas. ${ }^{158}$

According to a Safari Club International's article, the CAMPFIRE Program between 1989 and 2004 raised about US\$30 million, which was channelled back into the communities. ${ }^{159}$ Moreover, CAMPFIRE's impact on national income is at least US\$10 million annually. ${ }^{160}$ If the multiplier on tourism activities is included, CAMPFIRE is worth US\$2025 million to Zimbabwe's economic income each year. ${ }^{161}$ Periodic contributions have also come from USAID, FAO, Safari Club International Foundation, and the Kellogg Foundation. ${ }^{162}$

CAMPFIRE has been used as a model for similar programmes in southern and eastern Africa. ${ }^{163}$ It upholds that "hunting is an important conservation revenue source because trophy hunters often spend large amounts on hunting trips, including on licensed local professional guides, and on fees that generate revenues for communities."164 CAMPFIRE also sees hunting as having a limited environmental impact, given hunters' low numbers and resource demands compared to higher volume photographic and game viewing tourists, which typically require infrastructure that is not available in more remote areas used by hunters. ${ }^{165}$

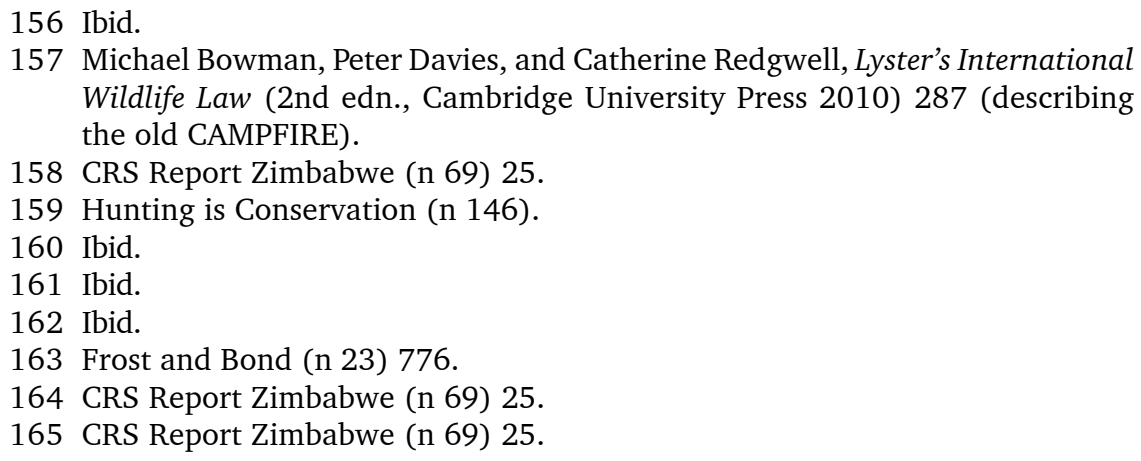


CAMPFIRE was developed largely around the concept of managing wildlife and its habitat in the communal lands of Zimbabwe for the benefit of the people living in these areas. ${ }^{166}$ CAMPFIRE contributes to job creation, empowerment, and diversification of livelihoods for rural communities. ${ }^{167}$ Some communities benefit from infrastructure such as clinics, schools, grinding mills, boreholes, and roads. ${ }^{168}$ Conversely, another study revealed that although the CAMPFIRE concept has been instrumental in creation of employment and infrastructure, the local community considers that no significant changes have occurred to their livelihoods. ${ }^{169}$

If the community benefits at all from CAMPFIRE, an average-sized family only earns from US $\$ 1$ to US $\$ 3$ annually, ${ }^{170}$ hence the assessment that the fire in the CAMPFIRE has run out. This is a disturbing reality, considering CAMPFIRE's vision of including the community in conserving their ecosystem and receiving benefits from proper management of their natural resources. Notably, the problem is CAMPFIRE benefits few people at the top of the pyramid; the local community is hardly benefiting from trophy hunting. ${ }^{171}$

A problem with CAMPFIRE is that decisions about resource management are most frequently made outside the local communities. ${ }^{172}$ CAMPFIRE was meant to create harmony among the

166 Frost and Bond (n 23) 777.

167 CRS Report Zimbabwe (n 69) 25. ("CAMPFIRE maintains projects focusing on hunting, a source of about ninety percent CAMPFIRE program funding income; community based tourism; rural enterprise development; and human-wildlife conflict mitigation.").

168 Hunting is Conservation (n 146).

169 Edward Mutandwa and Christopher Tafara Gadzirayi, "The Impact of community-based approaches to wildlife management: case study of the CAMPFIRE program in Zimbabwe" (2009) 14 International Journal of Sustainable Dev and World Ecology 336, 344.

170 British Broadcasting Company, "When is it hunting and when is it poaching?" (British Broadcasting Company (BBC), 29 July 2015) < http://www.bbc.com/ news/world-africa-33699347> accessed 29 April 2018. (But critics say that while tourism is a key revenue generator in many of the areas where hunting is common, less than $0.5 \%$ of the Zimbabwe's GDP comes from trophy hunting itself, and that the benefits often fail to reach ordinary Zimbabweans.).

171 CAMPFIRE Association, "Hunting is Low-Impact Tourism" (CAMPFIRE Association, 2017) < http://www.campfirezimbabwe.org/index.php/projectst/14-hunting $>$ accessed 29 April 2018.

172 Burns (n 19) 135. ("Wildlife tourism may bring considerable foreign exchange into a country ... [i]t is rare, however, especially in less-developed countries, 
local community, wildlife, and enhance the ecosystem as well as the natural habitat that each needed to continue their existence. ${ }^{173}$ However, under the CAMPFIRE programme, said a local spokesman, at least half of that revenue goes to the local communities for rural development and environmental conservation. ${ }^{174}$ This ideal was upheld; man can exist in harmony with wildlife and benefit from the conservation efforts brought about by CAMPFIRE; hence, the respect for trophy hunting was born. A local spokesperson states "[o]ur people have stopped poaching, they understand that a buffalo is worth much more if it is killed by a foreign hunter, an important principle to embrace hence propagating the local, national, regional as well as the international CITES' vision." 175

Nevertheless, there is a strong recognition that the participatory approach in wildlife conservation efforts is critical. ${ }^{176}$ In Zimbabwe, as elsewhere in Southern Africa, wildlife protection and sustainable environmental stewardship are widely pursued through communitybased natural resource management (CBNRM) programmes. ${ }^{177}$ The United Nations General Assembly resolution on "tackling illicit trafficking in wildlife" strongly encourages Member States to support the livelihoods of rural communities through engaging with them. ${ }^{178}$ It reinforces the imperative of involving the local community as partners who share their habitat with wildlife to participate in sustainable conservation projects as this will leverage their livelihoods and secure their rights to manage and benefit from wildlife. ${ }^{179}$

The core intent of CBNRM is to establish a socioeconomic stake in wildlife and other natural resources for communities by tying local livelihoods and economic incentives to sustainable resource

for this to result in tangible benefits at a household level due to "leakage" of tourist expenditure from the locality visited and the capture of financial benefits by a small elite within a community...").

173 IUCN (n 4) 2. (discusses that well managed trophy hunting generates revenue and incentives for the community to engage in wildlife conservation.).

174 CAMPFIRE Association (n 172).

175 Ibid ("However, given a steady income from trophy hunting, rural people are now motivated to conserve and manage their wildlife and have the funds to protect their villages and crops.").

176 CRS Report Zimbabwe (n 69) 25.

177 Ibid.

178 GA Res 71/L 88 (n 31).

179 GA Res 71/L 88 (n 31). 
management and environmental conservation efforts. ${ }^{180}$ However, today, Zimbabwe's CAMPFIRE is viewed differently, in light of the neglect of the local community; the questionable and inequitable financial distribution is the problem. This problem has taken the fire out of the CAMPFIRE where each of the tripartite objectives is ignored.

\section{PROPOSALS FOR REGULATORY REFORM IN ZIMBABWE}

If trophy hunting were to become unviable, the thousands of rural Zimbabwean households that directly benefit from CAMPFIRE would be further alienated and neglected to an impoverished existence. They would lose approximately US $\$ 1.7$ per year, which has been decreased due to the U.S. ban on imports of elephant's parts. ${ }^{181}$ Therefore, instead of completely banning trophy hunting, poor policies and practices could be reformed through amendments. The legal framework should be changed to promote the tripartite objectives, thus effectively implementing wildlife conservation, conferring benefits to the local community, and preserving the ecosystem. Reformation of the existing legal frameworks should also be achieved by implementing stronger sanctions, penalties, and strategies to alleviate further plundering through poaching and improve the current implementation of CITES and CAMPFIRE. These approaches will create teeth through amendments and muscle through greater enforcement to achieve their common objectives that safeguard the tripartite objectives.

Moreover, effective engagement with the local community will build sustainable grassroots management. The support from responsible national agencies ${ }^{182}$ to improve governance will also shape the success of the tripartite objectives. ${ }^{183}$ Historically, unregulated hunting in some continents led to the extinction of some wildlife. ${ }^{184}$ In recent times, declines in wildlife populations have been associated with illegal hunting, over harvesting, droughts, and fragmented and weak hunting policies that regulate harvesting of wildlife species. ${ }^{185}$

180 CRS Report Zimbabwe (n 69) 25.

181 IUCN (n 4) 8.

182 IUCN (n 4) 2.

183 Ibid.

184 Muposhi and others, "Trophy Hunting and Sustainability" (n 34) 2.

185 Ibid. 


\subsection{Proposed Amendments to International and Local Frameworks}

\subsubsection{Reforming CITES to Address Unsustainable Exemptions}

Current exceptions in CITES undermine the effective implementation of the Convention. Exceptions must be removed for Appendix I species unless the species can no longer be regarded as threatened. Furthermore, exceptions could be reasonably narrowed for the two remaining appendices. A potentially larger loophole is the use of reservations under Article XXIII, where countries have a right to opt out of the Convention with respect to any specific listing, ${ }^{186}$ which is a serious blunder in seeking a strong regulatory scheme in Appendix I. Article XXIII should be subordinated by the power of Appendix I that should change its listing only when the species is rendered no longer threatened but safe and abundantly sustainable for present and future generations.

Any reservation in relation to Appendix I may have serious and devastating consequences. Such reservations mean that the States shall be treated as a state and not a party to the treaty with respect to trade in a particular species, ${ }^{187}$ which may result in the decline of the wildlife that is already threatened. Article XXIII should only be used in limited circumstances for Appendix II species, and for Appendix III, which is usually based on a unilateral State's request. This adjustment would help CITES become a stronger and more effective conservation tool.

CITES' recognition that implementation of some listings, especially Appendix I listings, may adversely impact livelihoods of rural communities when this affects their employment and basic necessities, is commendable. ${ }^{188}$ However, this empathy must not justify the use and trade of threatened species. The recognition that local communities benefit from these species should be the very reason why they should be protected rather than adopt a fickle standard that will devastate the

186 Hunter and others (n 48) 1099. (Allowing reservations for threatened species fosters trophy hunting to exceed its quotas in pursuit of trade for countries that need foreign exchange at the expense of the wildlife's interests.).

187 Hunter and others (n 48) 1099.

188 CITES and Livelihoods, "Resolution Conference 16-6 Rev CoP17" (2017) <https://cites.org/sites/default/files/document/E-Res-16-06-R17.pdf> accessed 19 June 2018. 
communities even further when the species becomes extinct. Malleable rules tend to be superficial and unfruitful to propel the desired vision. It should be a non-negotiable rule that when a species is listed under Appendix I, the species cannot be down-listed unless it is no longer threatened or endangered.

America's suspension of transportation of elephant parts from Zimbabwe is an example of how wildlife may be protected when domestic $^{189}$ law of a foreign state prevails over international treaties that are insufficient to safeguard the wildlife's interests. In this case, despite Zimbabwe's submission of its report that its management of the wildlife was sustainable and in accordance with Appendix II of CITES, the U.S. was not convinced. ${ }^{190}$

The ban was initially justified by the USFWS' finding that Zimbabwean conservation plans did not adequately specify goals and progress towards conserving elephant populations. ${ }^{191}$ USFWS reinforced that the government had insufficient data with which to assess the status of its elephant populations and lacked adequate capacity to effectively implement and enforce elephant-related laws. ${ }^{192}$ The U.S. reasoned that although it facilitates imports of trophy hunting parts through Appendix II of CITES, it also stated that it is conditioned on Zimbabwe also satisfying standards that are set forth under the ESA, which have not been met. ${ }^{193}$

In late 2015, after a review of scientific and commercial information, USFWS also listed a subspecies of lion found in eastern and Southern Africa, Panthera leo melanochaita, as threatened under the ESA. ${ }^{194}$ Moreover, a concurrent rule was enforced in 2016, that restricted imports unless they complied with a strict and comprehensive process to ensure that such imports are legally sourced, ESA-compliant, and

189 International Fund for Animal Welfare (n 15) 17. ("Countries that are Parties to CITES can also pass laws that go beyond the guidelines of CITES.).

190 imbabwe Sanctions Regulations, Rules and Regulations, 79 Federal Register (2014), July 31, 2014, 44251 - 44633 "Notice of Continued Suspension of Zimbabwe Imports of Elephant Trophies taken on or After April 4, 2014".

191 USFWS Press Release (n 50). (USFWS further stated "[i]f we want to ensure that healthy lion populations continue to roam the African savannas and forests of India, it's up to all of us - not just the people of Africa and India - to take action.").

192 CRS Report Zimbabwe (n 69) 24.

193 Federal Register (n 191).

194 CRS Report Zimbabwe (n 69) 24. 
originate only from countries with well-managed, scientifically-based lion species conservation programmes. ${ }^{195}$ This sends another message that wildlife conservation must be achieved even if CITES lacks the power when a stricter foreign domestic ESA compliance rule stands as a stronger advocate for the wildlife's interest.

America's ban on transporting of elephant parts through its ESA should be emulated by other countries, where the stricter rule prevails to safeguard the wildlife's interests. ${ }^{196}$ The U.S. has taken steps to promote wildlife conservation in Zimbabwe, including by placing temporary bans on the import of sport-hunted elephant trophies and imposing permit requirements on lion imports. ${ }^{197}$ Consequently, the ESA's superseding of CITES required standards conveys that new standards must be accomplished to stop states from risking endangered or threatened species through importation of hunting trophies. In using the Endangered Species Act (ESA), ${ }^{198}$ the U.S. has set a pathway for other states to follow in suspending transportation of endangered animal parts. The private industry's response by airlines to stop transportation of animal parts after Cecil the Lion's death shapes the movement towards sustainability.

Moreover, the private sector played an integral role in the aftermath of Cecil the Lion, when the airlines' response was stronger than CITES after they banned transportation of endangered animals. They imposed a transportation moratorium that prohibits transportation of trophy animals and animal parts of endangered species from Zimbabwe, which included the Big Five. ${ }^{199}$

195 Ibid.

196 Zimbabwe Sanctions Regulations, Rules and Regulations 80 Federal Register 42,373-42,705, (July 17, 2015). (The suspension on importation of trophies taken during calendar year 2015 or future hunting seasons could be lifted if additional information on the status and management of elephants in Zimbabwe becomes available that satisfies the conditions of the 4(d) special rule under the Endangered Species Act.).

197 CRS Report Zimbabwe (n 69) Summary.

198 The Humane Society International (n 17) 6. ("Any U.S.-based hunter will require a USFWS permit to import lion trophies, which can only be issued if the killing enhances the survival of wild lion populations, a standard few hunts are likely to meet.").

199 Ibid 27. (discusses how the killing of Cecil the Lion drew global attention, condemnation, and calls for an end to lion hunting in Africa, and prompted several airlines to stop transport of animal trophies.). 
Despite the rhetoric that the airlines' embargo has been a result of the negative and emotive media framing of trophy hunting in Zimbabwe following the controversial killing of Cecil the Lion, ${ }^{200}$ the airlines are sending an important message about the importance of wildlife conservation. The argument that this negative media framing and imposition of embargos may render Zimbabwe a less attractive trophy hunting destination and have negative socioeconomic results ${ }^{201}$ may be outweighed by the ideal that wildlife possess the right to live. Unsustainable use and exploitation of natural resources is prohibited. It must not be justified to enhance economic pursuits, as this proves dire not only to the wildlife but to local communities and future generations when the ecosystem has been misused. The airlines' ban on transportation of endangered and threatened species' parts deters illicit trafficking of wildlife and thereby protects the wildlife. Consequently, CITES must change its implementation methods to incorporate new standards that do not allow for reservations, opting out, and exceptions when the existing legal framework is no longer effective to combat the decimation of wildlife.

\subsubsection{CAMPFIRE: Reigniting the Fire that Ran out of the Camp}

CAMPFIRE needs to be revived; it needs to adopt an unprecedented approach to manage the national and local funds that is integral to effect a positive change for both animal and human welfare. In order to set new standards of accountability and transparency, CAMPFIRE should create a Finance Task Force. This Task Force will include a significant representation of the local community not only made up of Rural District personnel but ordinary residents. There should be a rotational scheme for both professionals and locals, who will be able to serve in the Committee for a two-year term. This approach would prevent complacency that could potentially lead to corruption.

Furthermore, CAMPFIRE could be updated to allow the local communities to exercise their rights to sue for compensation. Local communities, under the amended CAMPFIRE, should be able to sue the Parks and Wildlife Management Authority pursuant to PAWA, Part II, Section (3); ${ }^{202}$ when they have suffered neglect, damage to property

200 Muposhi and others, "Trophy Hunting and Sustainability" (n 34) 3.

201 Ibid.

202 PAWA (n 9) Part II, § 3. 
and self, or loss of enjoyment due to poaching and use of their habitat. The loss of income and unrealized benefits should be considered and accounted for in a reasonable and objective manner. The inequitable system that allows a certain class to benefit and leave the poor local community to suffer must be reformed.

\subsubsection{The Need for Special Reporting and Monitoring Standards}

Special compliance and monitoring standards should be mainstreamed into the process of issuing permits or licenses to hunt, training professional hunters, and ensure the local community have been educated on the programme. Biannual reporting on the progress of adopting human rights based approach ${ }^{203}$ must be monitored, and data on the decline or increase of a species population through scientific findings must be reported. The pecuniary benefits must also be recorded, tracked, and measured to ascertain how much is being allocated to wildlife conservation, local community, and the ecosystem.

Requiring Environmental and Wildlife Contribution Certification to tourist hunters by educating them about the community and the impact of wildlife tourism will be part of the reform. Some individuals wish to conserve species for future generations and are prepared to pay for this effort. ${ }^{204}$ This represents an economic bequest value that will contribute towards resources geared to wildlife conservation, employing the local community to be anti-poaching rangers, and using their education to increase their understanding of the values of conservation. ${ }^{205}$ The certification may also include a tracking method that creates a record for a trophy hunter, their origin, their

203 Damilola S. Olawuyi, "Advancing Climate Justice in National Actions: The Promise and Limitations of the United Nations Human Rights-Based Approach" in Randall S. Abate (ed), Climate Justice: Case Studies in Global and Regional Governance Challenges (Environmental Law Institute 2016) 8 ("The Common Understanding on HRBA's... identifies the HRBA as a policy frame for mainstreaming human rights norms, standards, and principles into legislation, policies, and planning to ensure that citizens' interests are protected at all times.").

204 Clem Tisdell and Clevo Wilson, "Economics of Wildlife Tourism" in Karen Higginbottom (ed), Wildlife Tourism: Impacts, Management and Planning (Common Ground Publishing Pty Ltd 2004) 148.

205 Ibid. 
organizational affiliation, and the type of animal a trophy hunter has killed and wishes to hunt in the future.

This information will be useful to control excessive culling and hunting of a particular species. It will provide data on hunting trends that may be within the allocated quota or those that could possibly open doors to excessive killings beyond what is permitted. A trophy hunter that is always seeking to hunt an elephant may be stopped when an index of animal quota is available to show other options to prevent an endangered animal from being killed. The special compliance rules should be presented to CITES, SADC, PAWA and CAMPFIRE and must require that these reports be met via (i) Reporting the wildlife population; (ii) Showcasing incidents of poaching; (iii) Showing the reasonable precautionary steps available to combat poaching; and (iv) Ensuring that the names and positions of the appropriate parties who can be sued are clearly listed in order to be accountable for equitable distribution of benefits.

Through greater enforcement of CITES, the implementation through SADC's TFCA, PAWA, and CAMPFIREs will be enhanced through stronger sanctions. The reformed legal framework and the hands-on approach may prevent endangered species from being included in the allocated quota. Promoting photographic tourism for endangered species, particularly for Appendix I listings, is of paramount importance until such a time the wildlife numbers are sustainable. Appendices II and III listings may be assigned for a specific season to avoid a year of trophy hunting of a species. This approach to trophy hunting will improve Zimbabwe's wildlife management when trophy hunting is controlled by effective governance.

\subsubsection{Grassroots' Inspection Sites and Engagement with the Local Community}

Even CITES has recognized in its recent resolution that that poor rural communities may attach economic, social, cultural, and ceremonial importance to some CITES-listed species. ${ }^{206}$ Moreover, the new CAMPFIRE needs to be administered by putting this principle into practice: local communities must participate and be engaged in the process that affects their habitat and livelihoods. Additionally, the implementation of CITES is better achieved with the engagement of

206 CITES and Livelihoods (n 189). 
rural communities, especially those that are traditionally dependent on CITES-listed species for their livelihoods. ${ }^{207}$ The mandate for CITES to work closely on the ground with CAMPFIRE is essential for effective implementation of CITES listings, which may enhance livelihoods by delivering long-term species conservation and reducing unsustainable and illegal trade. ${ }^{208}$

Nevertheless, the recognition is a step towards understanding that the conservation of wildlife is possible when the local community is also involved in the initiatives to protect the wildlife from harm and extinction. This reinforces that the tripartite objectives are protected when laws recognize that they are not mutually exclusive but connected, and the implementation of the programmes are dependent on the local community. Furthermore, CITES recommends that parties adopt mitigation strategies for human-wildlife conflict with respect to CITESlisted species and that mitigation activities take into account not only CITES-listed species but also the ecosystem that contains them. ${ }^{209}$

Broad import restrictions can adversely affect conservation efforts, where "removing the incentives and revenue provided by hunting would be likely to cause serious declines of populations of a number of threatened or iconic species." 210 In order to collectively understand the risks involved in implementing a ban and the risk associated with continuing poor unregulated practices, the IUCN recommends the imperative to acknowledge significant negative impacts on species populations, habitat conservation, poaching levels, and the rights and livelihoods of indigenous and local communities. ${ }^{211}$ This reinforcement of the aforementioned proposals indicates that policy changes must consider the impact on the tripartite objectives and recognize their intertwined relationship. IUCN summons relevant decision-makers at all levels to ensure that any decision that could restrict or end trophy hunting programmes to be based first on careful and sound analysis with understanding of its role in conservation and the livelihoods of the local communities. ${ }^{212}$ There has also been lack of transparency in financial distribution from the trophy hunting's pecuniary benefits to

207 Ibid.

208 Ibid.

209 CITES and Livelihoods (n 189).

210 IUCN (n 4) 8.

211 Ibid 1.

212 Ibid. 
the indigenous and local communities. This lack of accountability could be attributed to the absence of representation from the local community. Lastly, IUCN's proposal cements the recurring theme in regulating sustainable trophy hunting that decisions ought to be made without decimating the indigenous and local community rights and livelihoods rendering equitable incentives to achieve enduring conservation efforts. $^{213}$

\subsubsection{Zimbabwe Cannot Afford a Complete Ban}

Comparative study will highlight how Zimbabwe differs politically and economically from Botswana; hence the former cannot afford a complete ban but could implement reformed and restrictive regulations. Botswana banned trophy hunting and, after CoP17's rejection to uplist Loxodonta Africana for Southern African countries, it unilaterally requested that its elephant population should be listed under Appendix I. Zimbabwe's push for an open market that allows legal commercial trading in ivory is based on its belief that the ivory ban has been a failure, because the black market exists and is being fed through poaching. Therefore restriction on ivory trade has not helped to conserve wildlife but has been part of the problem. ${ }^{214}$ Improved enforcement mechanisms are recommended to propagate meaningful wildlife tourism management that benefit the host community and enhances conservation efforts of the environment and biodiversity.

Zimbabwe cannot afford to implement a complete ban on trophy hunting due to its vulnerable socioeconomic status that is unlike Botswana's economic stability. The Department of the National Parks must work jointly with other departments to alleviate corruption in interrelated departments such as Tourism and Transportation. It must apply its own administrative rulings that are insulated from external influences. It also must implement a Trophy Hunting Task Force that will bring accountability and transparency and enhance local employment and engagement to eradicate poverty. The joint collaboration with Non-Governmental Organizations that are partners with United Nations and seek to achieve Millennium Development

213 Ibid.

214 CITES Zimbabwe's Proposal (n 126) 2. ("There have been only two "one-off sales" (1999 and 2008) 1 and the Appendix II countries realized only a fraction of the value of their ivory at these sales."). 
Goals should be helpful to garner resources towards sustainable results.

The regulatory weakness in legal trophy hunting as highlighted after Cecil the Lion's death can be reversed through reformation. The weaknesses include not keeping to the allocated quotas, hunting in the wrong locations, taking unauthorized species, misusing trophies to feed the illegal commercial market, and the growth of organized crime. ${ }^{215}$ Nonetheless, tourism and hunting can be complementary land uses in many areas when effective policies build a comprehensive sustainable wildlife management and viable land use. ${ }^{216}$ Effective new rules for customs, investigatory alliance among the Tourism, Transportation, and Department of National Parks and Wildlife Management should be working towards an anti-corruption system through a joint network.

In Zimbabwe, however, the trade-offs are quite high. In contrast to the stable political and socioeconomic status in Botswana, Zimbabwe's current economy cannot sustain a complete ban. It could be fatal for the wildlife, the local communities, and the ecosystem. ${ }^{217}$ Nevertheless, Botswana has encouraged wildlife photographic tourism that can still produce some income for the locals, whereas many African countries steadfastly support trophy hunting, including Zambia which is reinstating trophy hunting after a periodic suspension. ${ }^{218} \mathrm{~A}$ ban on trophy hunting will further cripple its economy and undermine the tripartite objectives. There have been, and continue to be, cases of poorly conducted and poorly regulated hunting. ${ }^{219}$ However, wellregulated trophy hunting programmes play an integral role in delivering benefits for both wildlife conservation and for the livelihoods and wellbeing of local communities living with wildlife. ${ }^{20}$ A blanket ban on

215 IUCN (n 4) 5.

216 Ibid 2.

217 Norimitsu Onishi, "A Hunting Ban Saps a Village's Livelihood” New York Times (12 September 2015) <https://www.nytimes.com/2015/09/13/world/ahunting-ban-saps-a-villages-livelihood.html> accessed 29 April 2018 ("The hunting ban has also meant a precipitous drop in income. Over the years, villagers had used money from trophy hunters, mostly Americans, to install toilets and water pipes, build houses for the poorest, and give scholarships to the young and pensions to the old.").

218 Ibid.

219 IUCN (n 4) 1.

220 Ibid (IUCN urges a push for urgent reform in trophy hunting, citing that there have been recorded incidents where trophy hunting has contributed to the decline of species.). 
trophy hunting would penalize good as well as bad practices. Such an overly broad rule would undermine these conservation and livelihood benefits.

\section{CONCLUSION}

The paradigm of sustainable trophy hunting or wildlife tourism is hypocritical and wrong in the minds of animal conservationists in many developed countries. Nevertheless, there is a growing recognition that balance is required in an approach to sustain wildlife, human communities, and the ecosystem. The tripartite objectives can be achieved by not adopting a mutually exclusive approach because each element needs others to maintain a sustainable natural cycle, which defines all life to be interdependent. The atrocious killing of wildlife disrupts the ecosystem.

In developing countries, as in Southern Africa, wildlife and the local community co-exist in close proximity, especially in rural areas. CITES needs to adopt amendments with teeth to enforce its laws, with more bite, and penalize lapses that enhance poaching. SADC'S shared resources approach, through its TFCA framework should be protected and be immune to changes of law or ban in trophy hunting as is the case with Botswana since strong regional alliances must be promoted to uphold the tripartite objectives. Once a success story, CAMPFIRE could be reignited through new standards, effective engagement, and involvement of each regulatory framework as it works in unison to enhance wildlife conservation and pass through benefits to the local community. The existing framework in Zimbabwe has failed to protect the lion from unlawful hunts - the elephant is prone to being poisoned, and the rhino is left to rot after bleeding to death. Nonetheless, a complete ban will further cripple the wildlife conservation efforts, diminish eradication of poverty for the local community, and alienate environmental preservation initiatives, which will devastate the tripartite objectives. 